\title{
Increase in efficiency of hydrogen production by optimization of food waste fermentation parameters
}

\author{
Vira Hovorukha ${ }^{1}$, \\ Oleksandr Tashyrev ${ }^{1}$, \\ Hanna Tashyreva ${ }^{1}$, \\ Olesia Havryliuk ${ }^{1}$, \\ Olena Bielikova ${ }^{1}$, \\ Larysa Iastremska ${ }^{2}$ \\ ${ }^{1}$ Zabolotny Institute of Microbiology \\ and Virology of the NASU, \\ Acad. Zabolotnogo St. 154, \\ 03143, Kyiv, Ukraine \\ vira-govorukha@ukr.net \\ ${ }^{2}$ National Aviation University, \\ Kosmonavta Komarova Ave. 1, \\ 02000, Kyiv, Ukraine
}

\begin{abstract}
The aim of the work was to optimize the ratio of weight of solid (food waste) and liquid (water) phases in order to ensure high efficiency of molecular hydrogen synthesis and degradation of multi-component food waste. Assessment of the efficiency of fermentation process was carried out using colorimetric and potentiometric methods for $\mathrm{pH}$ and redox potential measuring, volumetric and chromatographic methods for volume and composition of gas investigation, and mathematical calculations for fermentation parameters determination. The dynamics of hydrogen fermentation of waste in the horizontal reactor using different ratios of solid (food waste) and liquid (water) phases was investigated. The optimization of the ratio of solid and liquid phases was shown to lead to the increase in efficiency of molecular hydrogen synthesis and destruction of waste particles. The ratio of solid and liquid phases 1:3 was determined to be optimal for the effective synthesis of hydrogen as well as for maximum waste decomposition. It provided effective hydrogen fermentation of multi-component food waste and allowed to rationally use material and technical resources. Obtained results are promising for further development of efficient industrial biotechnologies for waste destruction with the simultaneous synthesis of environmentally friendly energy carrier, i.e. molecular hydrogen.
\end{abstract}

Keywords: hydrogen synthesis, multi-component solid food waste, dark fermentation, environmental biotechnologies

\section{INTRODUCTION}

Every year about 1.3 billion tonnes of food waste are accumulated in the world. Increasing volumes of multi-component food waste (MCFW) are a threat to the environment. As a result of its accumulation, air is polluted with toxic gases and soils are polluted with toxic landfill filtrate. Altogether it leads to diseases of humans and animals and destruction of ecosystems in general $[1,2]$.
The fermentation of MCFW with synthesis of environmentally friendly energy carrier molecular hydrogen is a promising direction in solving the problem of waste utilization. Application of $\mathrm{H}_{2}$ as environmentally friendly and renewable energy source is of interest not only to Ukraine, but also to many other countries in the world [3-5].

Compared to physical and chemical methods, technologies based on microbial synthesis of hydrogen do not require significant energy 
consumption, expensive catalysts (valuable metals), complex technological equipment, etc. [611]. Because of this reason microbial industrial biotechnologies of hydrogen synthesis are the most preferable [4].

Low-value waste from urban landfills and waste from multi-tonal industries such as $\mathrm{cu}$ linary, fruits and vegetables, molasses, surplus microbial biomass of treatment facilities should be used for the economically advantageous production of hydrogen $[3,4,9]$. Since the content of food waste in municipal waste reaches up to $20-54 \%$ [1], its use as a substrate for hydrogen synthesis allows efficient processing of environmentally hazardous substances and simultaneous production of hydrogen [3, 12-15].

Improvement of technology and development of the optimal waste fermentation mode will allow quick and efficient reduce of weight and volume of MCFW, as well as obtaining molecular hydrogen at the same time [5, 16-19].

Temperature, $\mathrm{pH}$, redox potential of culture fluid, speed and frequency of waste mass transfer, ratio of volumes of solid (waste) and liquid phases (water), etc. influence the efficiency of hydrogen fermentation of MCFW $[4,5,12]$.

Some of these parameters, including the ratio of solid and liquid phases, require careful research. The information that high concentration of organic waste in the reactor had led to decrease in hydrogen production efficiency was provided [12].

Therefore, the purpose of the investigation was to optimize the ratio of solid weight and liquid phases to ensure high efficiency of molecular hydrogen synthesis and degradation of multi-component food waste.

\section{MATERIALS AND METHODS}

The optimization of the weight ratio of solid and liquid phases was carried out in the horizontal reactor (Fig. 1). Its volume was 20 litres. Metal paddles for waste mixing were installed inside the reactor.

The mixture of food waste of the following composition was used for modelling of fermentation process (Fig. 2): raw and boiled potatoes in equal weight ratio (1 part); raw tomatoes, cucumbers, zucchini, cabbage, carrots, apples, parsley, chicken fillet, boiled pasta, bread in equal weight ratio (1 part).

Selected community of spore-forming hydrogen synthesizing microorganisms was used for rapid and effective destruction of MCFW. Its use provided high molecular hydrogen yield, high rate of waste particles destruction, and utilization of a wide range of food waste.

The regulation of microbial metabolism and provision of optimal parameters of the medium

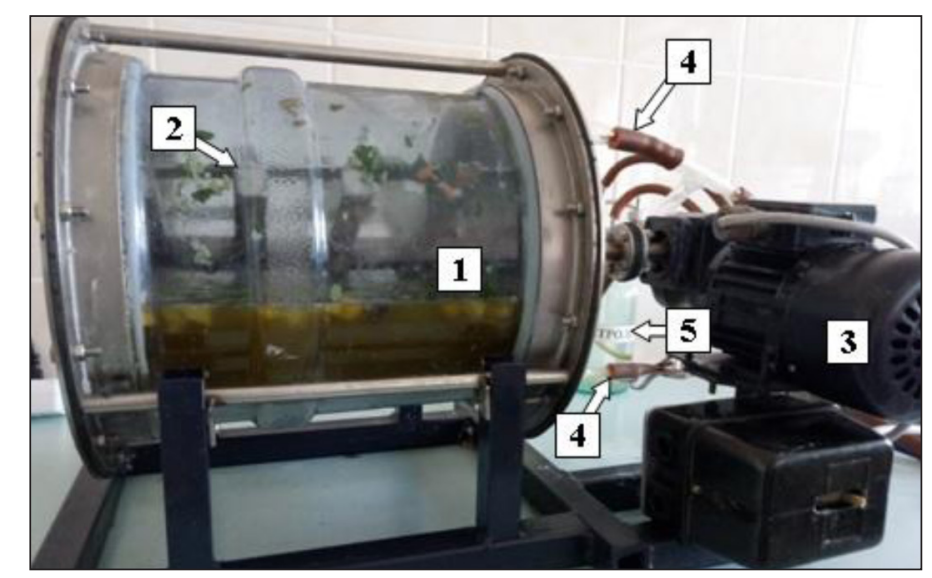

Fig. 1. General view of the horizontal reactor $(1-$ fermentation chamber of the reactor, 2 - paddles for waste mixing, 3 - motor providing waste mixing, 4 fittings for loading of regulators of microbial metabolism, collecting of culture fluid samples and discharging of synthesized gas, 5 - gas controller connected to gas holder) 


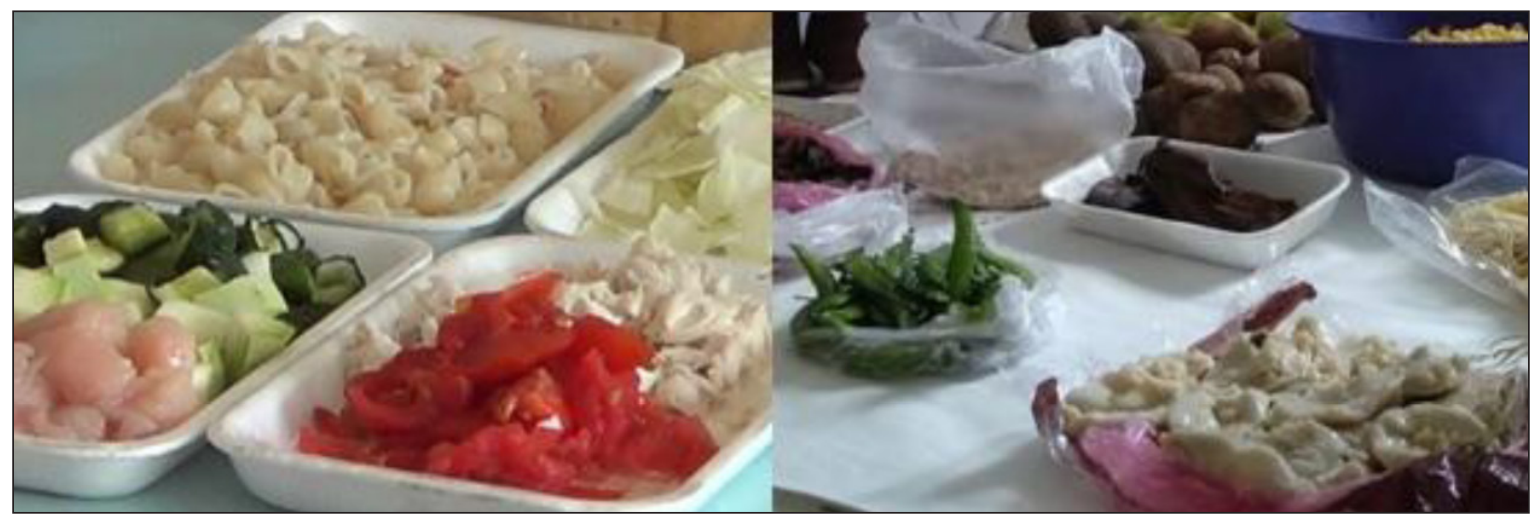

Fig. 2. Components of model for food waste mixture

for microorganisms was carried out using two types of specialized regulators of microbial metabolism. The saturated solution of $\mathrm{Na}_{2} \mathrm{CO}_{3}$ was used as the first one. It provided high rate of compensation of physical and chemical parameters of the culture medium if they deviated from optimal values. Its sterile solution was added to the medium periodically during the entire fermentation cycle to maintain optimal conditions for microbial growth. Also $\mathrm{CaCO}_{3}$ was constantly present in the medium and neutralized microbial exomatabolites as they were accumulated.

Bromothymol blue (BTB) was used as an indicator of microbial metabolism to provide visual express control of $\mathrm{pH}$ and redox potential of the medium. The concentration of BTB solution was $0.1 \%$. The colour of BTB dissolved in the culture medium varied with $\mathrm{pH}$ : at $\mathrm{pH}>7$ it was blue, at $\mathrm{pH}=7$ it was green, at $5<\mathrm{pH}<6$ it was yellow, and at $\mathrm{pH}=5$ it was yellow-hot. Visual control of redox potential was carried out by discoloration of BTB at $\mathrm{Eh}<-200 \mathrm{mV}$ ( $\mathrm{pH}=$ 6.0...7.8).

Tap water was used for fermentation of waste. It was boiled for 10 minutes and cooled to $35^{\circ} \mathrm{C}$ before its addition to the reactor.

The following components were added to the horizontal reactor: multi-component food waste pasteurized for 10 minutes, tap water, $20 \mathrm{~g}$ of microbial inoculum, $140 \mathrm{~g}$ of $\mathrm{CaCO}_{3}$, and $300 \mathrm{ml}$ of the indicator of microbial metabolism (BTB). The weight of waste and water was changed to achieve the optimal ratio of solid and liquid phases. If necessary, solution of $\mathrm{Na}_{2} \mathrm{CO}_{3}$ was added to the reactor during the time of cultivation. It provided optimal values of $\mathrm{pH}$ and $\mathrm{Eh}$ of the medium.

The vents of the reactor were tightly sealed with rubber stoppers with fittings. During the technological cycle, regulators of microbial metabolism were added through them by injection with a syringe, as well as the samples of culture liquid were taken and synthesized gas was discharged to the gas holder.

The reactor was connected to the gas controller and gas holder with rubber tubes. The gas controller was used for visual control of the intensity of gas synthesis. The gas holder was used for accumulation of synthesized gas and measuring of its volume.

The volume of gas was determined by the volume of water that was squeezed out of the gas holder into the receiving collector under the pressure of synthesized gas.

The following earlier optimized fermentation parameters were used during the cycle [20]:

- the rate of waste mixing (rotation rate of paddles in the reactor) - $24 \mathrm{rpm}$;

- the frequency of waste mixing (the ratio of duration of mixing to pause) - 15 minutes of mixing/30 minutes of pause.

The dynamics of the following parameters was monitored during hydrogen fermentation: $\mathrm{pH}$, Eh, volume and composition of gas mixture.

The fermentation cycle was going on for 7 days at temperature of $30^{\circ} \mathrm{C}$. Visual assessment of the degree of waste particles destruction, stabilization of $\mathrm{pH}(\mathrm{pH}=6.5-6.75)$, irreversible increase of Eh values of the medium from 
$-250 \ldots-350 \mathrm{mV}$ to $0 \ldots-100 \mathrm{mV}$, termination of gas synthesis, decrease in the concentration of hydrogen in the gas mixture evidenced the completion of the process.

The efficiency of molecular hydrogen synthesis and destruction of waste was investigated using the following ratios of solid and liquid phases: 1:1 (2 kg of waste and $2 \mathrm{~kg}$ of water); $1: 3$ (2 kg of waste and $6 \mathrm{~kg}$ of water); 1:6 (1 kg of waste and $6 \mathrm{~kg}$ of water).

The optimal ratio of solid and liquid phases provided the maximum molecular hydrogen yield and the highest efficiency of waste destruction.

The values of $\mathrm{pH}$ and redox potential (Eh) of the medium during fermentation were measured using potentiometric method ( $\mathrm{pH}$-meter-millivoltmeter " $\mathrm{pH}-150 \mathrm{MA}$ "). A porous glass electrode ESK-10603/4 was used to measure $\mathrm{pH}$. Redox potential was measured by platinum electrode EPV-1 and chlorine silver comparing electrode EVL-1M3.

Gas samples were collected from the gas holder by puncturing a rubber tube with a needle of plastic sterile syringes ("Bayer") with the volume of $2.5 \mathrm{ml}$. The content of gas was analysed according to the standard procedure on LHM-8-MD gas chromatograph [21]. The content of gas phase was calculated by the square of the peaks of its components.

The chromatograph was equipped with two steel columns: the first (I) was used for analysis of $\mathrm{H}_{2}, \mathrm{O}_{2}, \mathrm{~N}_{2}$ and $\mathrm{CH}_{4}$, the second (II) was used for analysis of $\mathrm{CO}_{2}$. The parameters of the columns were: $I$ was $l=3 \mathrm{~m}, d=3 \mathrm{~mm}$, with molecular sieve 13X $(\mathrm{NaX})$; II was $\mathrm{l}=2 \mathrm{~m}, d=3 \mathrm{~mm}$ with porapak-Q carrier. Column temperature was $+60^{\circ} \mathrm{C}$, evaporator temperature was $+75^{\circ} \mathrm{C}$, detector temperature (catharometer) was $+60^{\circ} \mathrm{C}$; detector current was $50 \mathrm{~mA}$; argon was gas carrier; gas flow rate was $30 \mathrm{~cm}^{3} / \mathrm{min}$.

The determination of the optimal ratio of solid and liquid phases during hydrogen fermentation of multi-component food waste was carried out as a result of analysis of the following engineering and technological parameters of fermentation:

1) duration of technological cycle ( $T$, days) is the time of waste destruction till the moment of maximum destruction of waste particles and stabilization of parameters of the culture medium (first of all, termination of gas synthesis);
2) molecular hydrogen yield is the amount of synthesized molecular hydrogen (in liters) from $1 \mathrm{~kg}$ of waste (calculated to absolutely dry weight or ADW);

3) coefficient of waste destruction $(K d)$ is the ratio of initial and final dry weight of solid waste calculated.

\section{RESULTS AND DISCUSSION}

The efficiency of molecular hydrogen synthesis and waste destruction during their fermentation depends on the temperature, $\mathrm{pH}$, redox potential of the medium, size of waste particles, frequency and speed of mixing of waste, ratio of solid (solid waste particles) and liquid (water) phases, etc.

Microorganisms during the process of fermentation of MCFW synthesize exometabolites accumulated in culture fluid and lead to changes of physical and chemical parameters of the culture medium. The accumulation of microbial exometabolites in high concentrations [22] obligatorily leads to inhibition of microbial growth that leads to inhibition of molecular hydrogen synthesis and process of waste destruction in general.

The determination of the optimal ratio of solid and liquid phases during hydrogen fermentation of MCFW is a promising way to prevent accumulation of microbial exometabolites that could significantly decrease the efficiency of the process of waste fermentation. Optimization of the ratio of solid and liquid phases will ensure high efficiency of hydrogen synthesis and waste destruction.

Determining the optimal ratio of solid and liquid phases, it is necessary to take into account that advantage for industrial application is given to the increase in weight of waste with minimal addition of water. This ratio reduces the costs associated with the use of large volumes of reactors, additional technological operations for its loading and unloading, etc. However, on the other hand, the use of such ratio concentration of organics in culture liquid is high.

Active development of microorganisms during fermentation of waste leads to rapid accumulation of microbial exometabolites in culture fluid, mainly organic acids. High concentration of organic acids leads to catastrophic decrease in 
$\mathrm{pH}$ of the medium and inhibition of microbial growth. As a result, the process of waste destruction and hydrogen synthesis is inefficient $[4,23]$.

Increase in the volume of the liquid phase can prevent catastrophic acidification of the medium during the growth of microorganisms. Consequently, there is no inhibition of their growth, therefore efficiency of hydrogen fermentation of waste increases. However, such ratio of solid and liquid phases leads to increased costs for servicing large volumes of reactors, as well as the problems associated with disposal of large volumes of culture fluid after completion of the fermentation cycle.

Therefore, the determination of the optimal ratio of weight of solid and liquid phases will solve a range of problems, such as: to prevent rapid suppression of microbial growth and process of fermentation in general as a result of rapid accumulation of exometabolites in high concentrations; to minimize costs associated with servicing large volumes of culture liquid and reactors; to achieve maximum efficiency of the process of molecular hydrogen synthesis and waste destruction.

Optimization of the ratio of solid and liquid phases was carried out during fermentation of multi-component food waste in the horizontal reactor (Fig. 1). This reactor was used for the modelling of fermentation of industrial food waste and obtaining fermentation parameters of the process. Obtained parameters can be the base for scaling the process of waste destruction with simultaneous obtaining of hydrogen in future.

The ratio of solid and liquid phases was found to be optimal if the maximum molecular hydrogen yield and the highest efficiency of waste destruction were achieved.

First of all, the investigation of the effectiveness of molecular hydrogen synthesis and waste destruction was carried using the ratio of solid and liquid phases 1:1 (Fig. 3). This ratio was chosen first as the most desirable, since it allows operating with minimal volumes of water and to reduce the costs of additional technological operations. Using the ratio of solid and liquid phases 1:1 microbial growth was inhibited that led to low hydrogen yield and inefficient destruction of waste particles. During fermentation of organics in high concentration, the amount of microbial exometabolites in the medium grew rapidly. Accumulation of acidifying metabolites inevitably led to a sharp decrease of medium $\mathrm{pH}$. The value of $\mathrm{pH}$ dropped from 6.9 to 4.65 after 12 hours of cultivation. It led to inhibition of microbial growth. $\mathrm{CaCO}_{3}$ during such a sharp decrease of $\mathrm{pH}$ could not compensate negative changes. Therefore, $\mathrm{Na}_{2} \mathrm{CO}_{3}$ during 48 hours of cultivation had to be added regularly to maintain $\mathrm{pH}$ within the optimal values (Fig. 3).

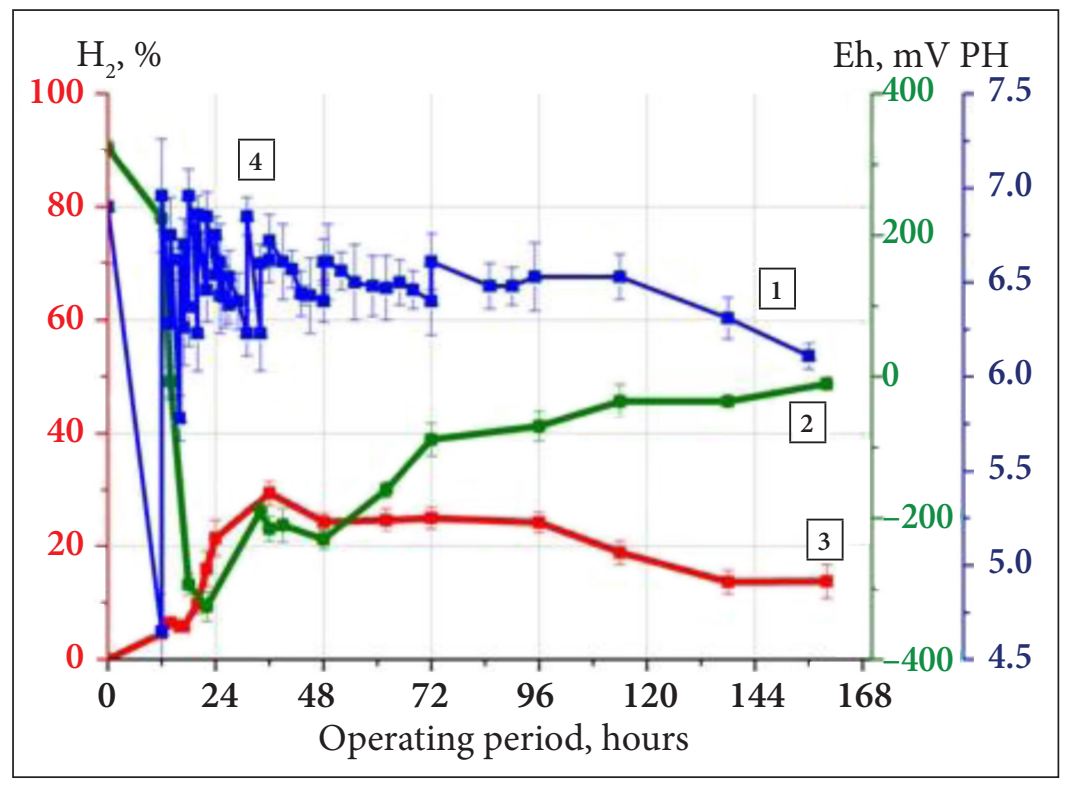

Fig. 3. Dynamics of hydrogen fermentation of multi-component food waste using the ratio of solid and liquid phases 1:1:1) pH;2) Eh; 3) $\mathrm{H}_{2}$ concentration; 4) fractional addition of $\mathrm{Na}_{2} \mathrm{CO}_{3}$ 
The dynamics of redox potential values also evidenced inhibition of microbial growth. Although the value of Eh decreased from $+323 \mathrm{mV}$ to $-325 \mathrm{mV}$ during 22 hours, but in the future there was only a rise in the redox potential values. Eh was $-70 \mathrm{mV}$ after 96 hours. The value of redox potential in the range of $-300 . . .-200 \mathrm{mV}$ contributed to effective synthesis of hydrogen, but rapid increase of Eh values reduced its efficiency.

The maximum concentration of molecular hydrogen (29.4\%) was achieved after 36 hours of cultivation. The volume of synthesized gas was 76 litres during all time of waste fermentation.

The duration of the technological cycle $(T)$ was 6.5 days. The coefficient of waste destruction $(K d)$ was low, only 5.11 . The yield of synthesized hydrogen was only 34.6 litres from $1 \mathrm{~kg}$ of waste in terms of ADW of waste.

Consequently, the ratio of solid and liquid phases $1: 1$ is not optimal since it did not provide efficient waste destruction $(K d=5.11)$ and synthesis of molecular hydrogen (yield of hydrogen was $34.6 \mathrm{~L} / \mathrm{kg}$ of waste). At such ratio, there was a rapid accumulation of microbial exometabolites that led to catastrophic acidification of the medium and inhibition of microorganisms. In order to compensate negative changes, it was necessary to regularly use $\mathrm{Na}_{2} \mathrm{CO}_{3}$. It led to additional use of the regulator, as well as addition- al technological operations. That is why we increased the ratio of solid and liquid phases.

Fermentation of MCFW using the ratio of solid and liquid phases of 1:3 provided effective destruction of waste and synthesis of molecular hydrogen (Fig. 4).

At lower concentrations of organic substances, the values of $\mathrm{pH}$ decreased more slowly, compared with the previous ratio. The $\mathrm{pH}$ reached minimum values from 7.09 to 5.78 during 11 hours of cultivation. Regulation of $\mathrm{pH}$ value using $\mathrm{Na}_{2} \mathrm{CO}_{3}$ had to be carried out only during 28 hours of cultivation. Thus, such ratio provided effective regulation of $\mathrm{pH}$ and hydrogen synthesis.

The value of redox potential in this case also provided conditions for effective destruction of waste and synthesis of hydrogen. Thus, Eh decreased from $+324 \mathrm{mV}$ to $-302 \mathrm{mV}$ only for 23 hours and remained within the values optimal for hydrogen fermentation of waste $(-250 \ldots-350 \mathrm{mV})$ throughout the cycle.

Maximum concentration of hydrogen (44.3\%) was reached after 31 hours of cultivation. The total volume of synthesized gas during the entire fermentation cycle was 182 litres.

High efficiency of fermentation using the ratio of solid and liquid phases 1:3 was indicated by determined engineering and technological parameters. The yime of waste destruction $(T)$ was very

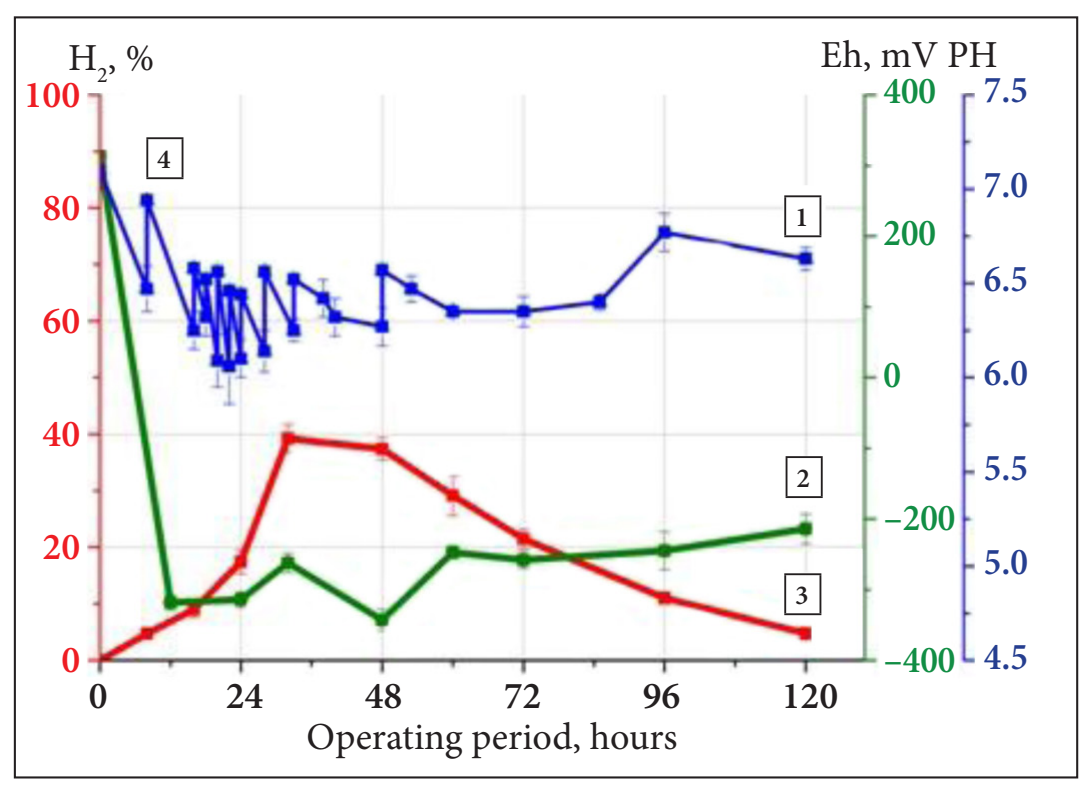

Fig. 4. Dynamics of hydrogen fermentation of multi-component food waste using the ratio of solid and liquid phases 1:3: 1) pH; 2) Eh;3) $\mathrm{H}_{2}$ concentration; 4) fractional addition of $\mathrm{Na}_{2} \mathrm{CO}_{3}$ 
short (4 days). The coefficient of waste destruction $(K d)$ increased by 18 times and was 93 . The yield of molecular hydrogen increased by 3.6 times and was $123 \mathrm{~L} / \mathrm{kg}$ of waste counting to ADW.

Thus, the ratio of solid and liquid phases of $1: 3$ contributed to the effective destruction of waste particles and synthesis of molecular hydrogen. It was confirmed by determined engineering and technological parameters of fermentation. Using such ratio changes in physical and chemical conditions of the medium occurred gradually. It allowed to regulate microbial metabolism effectively and to ensure high efficiency of the process of hydrogen fermentation of waste.

Obtained results led to the assumption that reduction of the concentration of waste during their fermentation can contribute to increase in the efficiency of hydrogen synthesis and waste destruction, as well as reduction of technological cycle duration.

Reduction of the concentration of waste during their fermentation should slow down accumulation of microbial exometabolites in the culture fluid that could inhibit microbial growth and reduce the effectiveness of hydrogen synthesis and waste destruction.

To test this assumption, fermentation of MCFW was carried out using the ratio of solid and liquid phases of 1:6 (Fig. 5).
Using such ratio the $\mathrm{pH}$ values changed gradually. So the need for regulation was only during the first day of cultivation. The $\mathrm{pH}$ decreased insignificantly from 7.06 to 5.68 after 15 hours of cultivation. Subsequently, periodically it was necessary to maintain it within the optimum values with the help of $\mathrm{Na}_{2} \mathrm{CO}_{3}$.

The optimal values of redox potential within the range $-253 \ldots-325 \mathrm{mV}$ were achieved after 18 hours of cultivation. However, the value of Eh began to increase after 40 hours of cultivation indicating the gradual completion of fermentation process.

Maximum concentration of molecular hydrogen was $53 \%$ after 43 hours of cultivation. Total volume of synthesized gas was 67.5 litres.

An assessment of the efficiency of waste destruction and synthesis of hydrogen was carried out by analysing fermentation parameters of fermentation. Thus, the time of waste destruction $(T)$ was 3 days. The coefficient of waste destruction $(K d)$ was 66.7. The yield of hydrogen amounted to $127 \mathrm{~L} / \mathrm{kg}$ of waste in terms of ADW.

Consequently, the ratio of solid and liquid phases 1:6 achieved the highest efficiency of molecular hydrogen synthesis. In addition, the duration of the technological cycle of fermentation was the shortest. However, the efficiency of waste destruction was 1.4 times lower compared to the

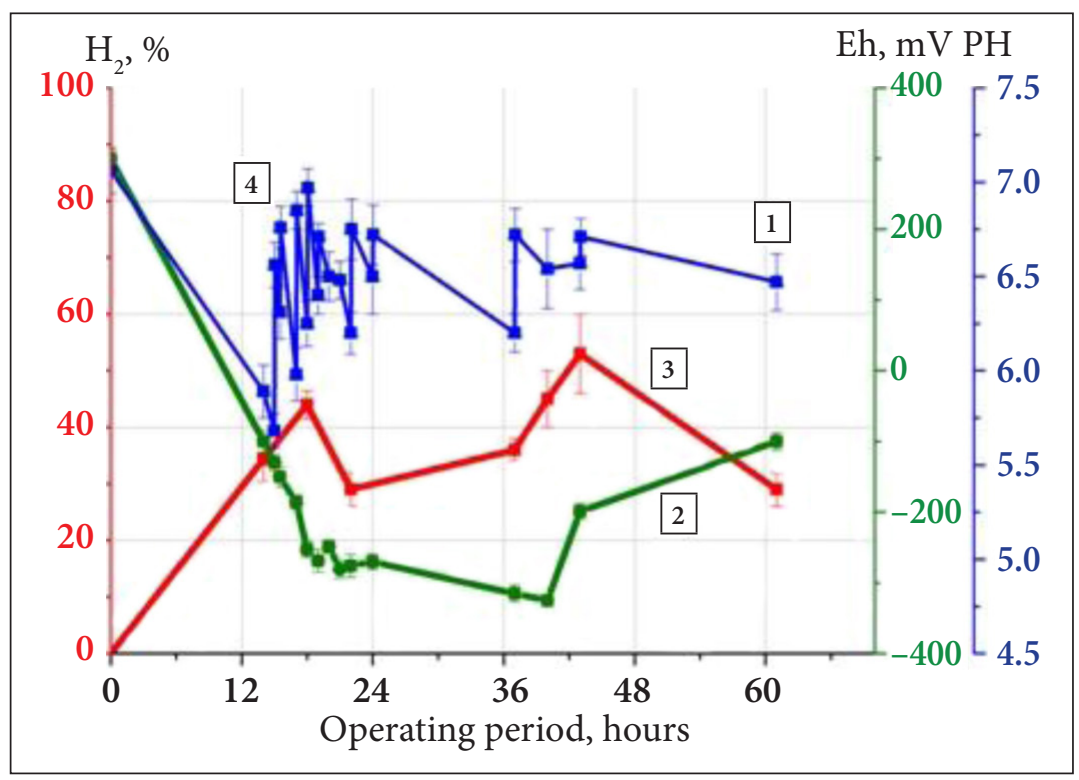

Fig. 5. Dynamics of hydrogen fermentation of multi-component food waste using the ratio of solid and liquid phases 1:6: 1) pH; 2) Eh;3) $\mathrm{H}_{2}$ concentration; 4) fractional addition of $\mathrm{Na}_{2} \mathrm{CO}_{3}$ 
results of fermentation using the ratio of solid and liquid phases 1:3.

Thus, among the investigated ratios of solid and liquid phases, 1:1 is ineffective for hydrogen fermentation of food waste (Table 1). High concentration of organic acids (microbial exometabolites) that were intensively accumulated in the culture medium led to its catastrophic acidification, inhibition of microorganisms and fermentation process in general.

The ratio of solid and liquid phases 1:6 provided high efficiency of molecular hydrogen synthesis during the shortest time (Table 1). It was evidenced by the highest values of hydrogen yield in $127 \mathrm{~L} / \mathrm{kg}$ of waste. However, the coefficient of waste destruction $(K d)$ was only 66.7. Unfortunately, we cannot explain the reason for such a low coefficient of waste destruction $(K d)$. It was to be expected that increase in the volume of the liquid phase would lead to decrease in the content of toxic exometabolites and increase in effectiveness of waste destruction. However, it did not happen. In the future we will study this unusual phenomenon.

On the other hand, according to the results of fermentation using the ratio of solid and liquid phases 1:3, the similar values of hydrogen yield were obtained (Table 1). However, the coefficient of waste destruction $(K d)$ was 1.4 times greater.

Thus, fermentation parameters using the ratios of solid and liquid phases 1:3 and 1:6 were similar, and $K d$ was 1.4 times greater than the ratio $1: 3$. Hence, the ratio of solid and liquid phases $1: 3$ was optimal for effective waste destruction and molecular hydrogen synthesis. In addition, the possibility to use 2 times less volume of water is also its advantage. The use of minimum volumes is industrially promising as it avoids working with large volumes of reactors and applying additional technological operations.
Consequently, the ratio of solid and liquid phases 1:3 was optimal both for obtaining the highest values of fermentation parameters and for the efficient use of material and energy resources.

According to literature data, solid organic waste at the concentration of 5-120 g/L was used there. The concentration of solids $90 \mathrm{~g} / \mathrm{L}$ was found to be optimal for maximum hydrogen yield $(2.2 \mathrm{~L} / \mathrm{kg})$. However, the results obtained under such conditions differed and required clarification [12].

According to the results of the investigation, environmentally hazardous multi-component organic waste modelled during fermentation was shown to be perspective substrate for fermentation with hydrogen obtaining [9, 24, 25]. Maintaining of optimal parameters for microbial growth provided effective destruction of solid waste particles with simultaneous obtaining of environmentally friendly energy carrier, i.e. molecular hydrogen $[26,27]$.

Thus, the optimal ratio of solid and liquid phases 1:3 provided the most effective hydrogen fermentation of organic waste.

\section{CONCLUSIONS}

The optimization of the ratio of solid (food waste) and liquid (water) phases during hydrogen fermentation of waste in the horizontal batch reactor was shown to lead to the increase in efficiency of molecular hydrogen synthesis and destruction of waste particles. The ratio of solid and liquid phases 1:1 was established to be the worst, as it led to simultaneous inhibition of microbial growth and fermentation process in general. The ratio of solid and liquid phases 1:6 was shown to be effective for synthesis of hydrogen, but led to decrease in efficiency of waste destruction and very undesirable increase in the total volume of fermentation

Table 1. Fermentation parameters depending on the ratio of solid and liquid phases in the reactor

\begin{tabular}{c|c|c|c|c}
\hline \multirow{2}{*}{ No. } & \multirow{2}{*}{ Fermentation parameter } & \multicolumn{3}{|c}{ The ratio of solid and liquid phases } \\
\cline { 3 - 5 } & & $\mathbf{1 : 1}$ & $\mathbf{1 : 3}$ & $\mathbf{1 : 6}$ \\
\hline 1 & Coefficient of destruction $(K d)$ & 5 & 93 & 67 \\
\hline 2 & Duration of technological cycle $(T)$, days & 6.5 & 4 & 3 \\
\hline 3 & $\mathrm{H}_{2}$ concentration, $\%$ & 30 & 44 & 53 \\
\hline 4 & $\mathrm{H}_{2}$ yield, $\mathrm{L} / \mathrm{kg}$ & 35 & 123 & 127 \\
\hline
\end{tabular}


mixture. The ratio of solid and liquid phases 1:3 was determined to be optimal for the effective synthesis of hydrogen as well as for maximum waste decomposition. It provided effective hydrogen fermentation of multi-component food waste and allowed rationally use material and technical resources. Obtained results are promising for further development of efficient industrial biotechnologies for waste destruction with the simultaneous synthesis of environmentally friendly energy carrier, i.e. molecular hydrogen.

Received 4 November 2018 Accepted 10 January 2019

\section{References}

1. Yasin N., Mumtaz T., Hassan M., Rahman N. Food waste and food processing waste for biohydrogen production: A review. Journal of Environmental Management. 2013. Vol. 130. P. 375-385.

2. Kiran E. U., Trzcinski A. P., Ng W. J., Liu Y. Bioconversion of food waste to energy: A review. Fuel. 2014. Vol. 134. P. 389-399.

3. Andriichuk I. L. et al. Fundamental Problems of Hydrogen Energetics (under review of Pokhodenko V. D., Skorokhod V. V., Solonin Iu. M.). Kiev: KIM, 2010. 495 p.

4. Ghimire A., Frunzo L., Pirozzi F. et al. A review on dark fermentative biohydrogen production from organic biomass: Process parameters and use of by-products. Applied Energy. 2015. Vol. 144. P. 73-95.

5. Ghimire A., Sposito F., Frunzo L. et al. Effects of operational parameters on dark fermentative hydrogen production from biodegradable complex waste biomass. Waste Management. 2016. Vol. 50. P. 55-64.

6. Kotay S. M., Das D. Microbial hydrogen production with Bacillus coagulans IIT-BT S1 isolated from anaerobic sewage sludge. Bioresource Technology. 2007. Vol. 98. No. 6. P. 183-190.

7. Levin D. B., Pitt L., Love M. Biohydrogen production: prospects and limitations to practical application. International Journal of Hydrogen Energy. 2004. Vol. 29. P. 173-185.

8. Kim H. Y. A low cost production of hydrogen from carbonaceous wastes. International Journal of Hydrogen Energy. 2003. Vol. 28. P. 1179-1186.
9. Kapdan I. K., Kargi F. Bio-hydrogen production from waste materials. Enzyme and Microbial Technology. 2006. Vol. 38. P. 569-582.

10. Tarasov B. P., Lototskii M. V. Hydrogen energetics: past, present, future views. Rossiiskii Chimicheskii Journal. 2006. Vol. L. No. 6. P. 5-18.

11. Nath K., Das D. Biohydrogen production as a potential energy resource - Present state-of-art. Journal of Scientific \& Industrial Research. 2004. Vol. 63. P. 729-738.

12. Moreno-Andrade I., Buitrón G. Evaluation of particle size and Initial concentration of total solids on Biohydrogen production from food waste. Fresenius Environmental Bulletin. 2015. Vol. 24. No. 7. P. 2289-2295.

13. Ren N. et al. Biohydrogen production from molasses by anaerobic fermentation with a pilotscale bioreactor system. International Journal of Hydrogen Energy. 2006. Vol. 31. P. 2147-2157.

14. Das D., Veziroglu T. N. Advances in biological hydrogen production processes. International Journal of Hydrogen Energy. 2008. Vol. 33. P. 6046-6057.

15. Wang S., Zhu Y., Zhang Y., Li Y. Controlling the oxidoreduction potential of the culture of Clostridium acetobutylicum leads to an earlier initiation of solventogenesis, thus increasing solvent productivity. Applied Microbiology and Biotechnology. 2012. Vol. 93. No. 3. P. 1021-1030.

16. Sivagurunathana P., Senabc B., Lin C. Y. Overcoming propionic acid inhibition of hydrogen fermentation by temperature shift strategy. International Journal of Hydrogen Energy. 2014. Vol. 39. No. 33. P. 19232-19241.

17. Ntaikou I., Antonopoulou G., Lyberatos G. Biohydrogen production from biomass and wastes via dark fermentation: a review. Waste Biomass Valor. 2010. Vol. 1. P. 21-39.

18. Morris E. L., Henneberger R., Huber H., MoisslEichinger C. Microbial syntrophy: interaction for the common good Brandon. Microbiology Reviews. 2013. Vol. 37. P. 384-406.

19. Tashyreva A. Tashyrev O., Prytula I. The novel comprehensive approach for non-food agricultural and landfill biomass microbial fermentation and biogas production. In: R. K. Behl, E. Arseniuk (eds.). Biotechnology and Plant Breeding Perspectives. Agrobios (International) Publishers, 2014. P. 347-356. 
20. Tashyreva H., Tashyrev O., Govorukha V., Havryliuk $\mathrm{O}$. The effect of mixing modes on biohydrogen yield and spatial $\mathrm{pH}$ gradient at dark fermentation of solid food waste. Ecological Engineering and Environment Protection. 2017. Vol. 2. P. 53-62.

21. Drugov Iu. S., Berezkin V. G. Gas Chromatographic Analysis of Polluted Air. Moskva: Chimia, 1981. $256 \mathrm{p}$.

22. Prytula I., Tashyrev O., Matveeva N. Microbial synthesis of hydrogen for the fermentation of organic compounds. Youth and the Progress of Biology: A Collection of Theses of the VII International Scientific Conference of Students and Graduate Students, April 5-8, 2011, Lviv, Ukraine. P. 271.

23. Cheng H., Whang L., Wu Ch., Chung M. A twostage bioprocess for hydrogen and methane production from rice straw bioethanol residues. $B i$ oresource Technology. 2012. Vol. 113. P. 23-29.

24. Insam H., Gómez-Brandón M., Ascher J. Manure-based biogas fermentation residues - friend or foe of soil fertility?. Soil Biology and Biochemistry. 2015. Vol. 84. P. 1-14.

25. Ting C. H., Lee D. J. Production of hydrogen and methane from wastewater sludge using anaerobic fermentation. International Journal of Hydrogen Energy. 2007. Vol. 32. P. 677-682.

26. Nguyen T.-A. D. et al. Hydrogen production of the hyperthermophilic eubacterium, Thermotoga neapolitana under $\mathrm{N}_{2}$ sparging condition. Bioresource Technology. 2010. Vol. 101. P. 38-41.

27. Ntaikou I. et al. Hydrogen production from sugars and sweet sorghum biomass using Ruminococcus albus. International Journal of Hydrogen Energy. 2008. Vol. 33. P. 1153-1163.
Vira Hovorukha, Oleksandr Tashyrev, Hanna

Tashyreva, Olesia Havryliuk, Olena Bielikova, Larysa Iastremska

\section{VANDENILIO GAMYBOS EFEKTYVUMO DIDINIMAS OPTIMIZUOJANT MAISTO ATLIEKŲ FERMENTACIJOS PARAMETRUS}

\section{Santrauka}

Straipsnyje pateikto darbo tikslas - optimizuoti kietųjų (maisto atliekų) ir skystųjų (vandens) fazių svorio santykį, siekiant užtikrinti aukštą molekulinio vandenilio sintezès efektyvumą ir daugiakomponenčių maisto atliekų skaidymą. Fermentacijos proceso efektyvumo vertinimas buvo atliktas naudojant kolorimetrinius ir potenciometrinius $\mathrm{pH}$ ir redokso potencialo matavimo metodus, tūrio ir chromatografijos metodus tūriui ir dujų sudèties tyrimui bei fermentacijos parametrų nustatymo matematinius skaičiavimus. Ištirta vandenilio fermentacijos iš atliekų horizontaliame reaktoriuje naudojant skirtingus kietụjų (maisto atliekų) ir skystųjų (vandens) fazių santykius dinamika. Nustatyta, kad kietųjų ir skystųjų fazių santykio optimizavimas skatina molekulinio vandenilio sintezės efektyvumą ir atliekų dalelių naikinimą. Kietųjų ir skystųjų fazių 1:3 santykis yra optimalus efektyviai vandenilio sintezei ir maksimaliam atliekų skaidymui. Tai veiksmingai fermentavo vandenilị iš daugiakomponenčių maisto atliekų ir leido racionaliai naudoti materialinius ir techninius išteklius. Gauti rezultatai patvirtina, kad perspektyvu toliau plètoti efektyvias pramonines biotechnologijas siekiant naikinti atliekas, taip pat sintezuoti aplinką tausojantị energijos nešikli, t. y. molekulinị vandenilį.

Raktažodžiai: vandenilio sintezè, kelių komponentų kietosios maisto atliekos, tamsi fermentacija, aplinkos biotechnologijos 